\title{
Students involvement in achieving creative goals within a digital educational environment
}

\author{
Leonid Mihajlovich Popov ${ }^{1}$ and Pavel Nikolaevich Ustin ${ }^{2 *}$ \\ ${ }^{1}$ Kazan (Volga region) Federal University, Department of Clinical Psychology and Psychology of \\ Personality, Institute of Psychology and Education, Kazan, Russia \\ ${ }^{2}$ Kazan (Volga region) Federal University, Department of General Psychology, Institute of Psychology \\ and Education, Kazan, Russia
}

\begin{abstract}
During the COVID-19 pandemic, the educational process acquired distance learning techniques when technical teaching aids gained much more significance for mediating the real interaction of students and their teachers. At the same time, emotional-intonational interaction (the main method of imposing influence) became extremely limited. The conditions for creating the effect of involvement have changed and scholars need to consider the phenomenon of involvement, its psychological mechanisms, strategies used by teachers and students in digital learning. The research objective is to determine the model of involvement of participants in educational activity in the context of distance (digital) learning based on the analysis of the Russian and foreign approaches to the types and aspects of involvement. The main aspects of involvement include cognitive, emotional, behavioral, activity-based, motivational, socio-psychological and physical. These aspects represent the external and internal factors of the spatial side of the personality-based activity model. The novelty of the spatial and temporal model consists in the use of all spatial factors in sequent time phases of involvement: preparatory, activity-based, evaluativecorrectional. The preparatory phase has emotional, motivational and semantic aspects. The activity-based phase comprises cognitive-behavioral and socio-psychological aspects. The evaluative-correctional phase aims at assessing both preparatory and activity-based phases according to the following system: A-high, B-moderate, C-low. The decision to adjust involvement is based on expert assessments (AA, AB, BA, AC, etc.). The authors suggest long-term and short-term options for implementing the involvement model with their methods, expected results and implementation mechanisms. The short-term version of the involvement model is realized through the digital monitoring of emotional and cognitive responses of a person in a digital environment. The authors also highlight the possibility of managing and self-managing students' involvement in educational activities within a digital environment.
\end{abstract}

Keywords: involvement, participants in educational activity, the digital monitoring of involvement.

\footnotetext{
* Corresponding author: pavust@mail.ru
} 


\section{Introduction}

The relevance of studying the phenomenon of "involvement" in the digital educational environment increased during the COVID-19 pandemic when distance learning replaced traditional contact forms of education. The conditions for creating the effect of involvement have changed and we need to consider the phenomenon of involvement, its psychological mechanisms and strategies used by teachers and students in digital learning. The material and teaching experience accumulated by various scholars promotes the creation of different models to ensure student-teacher involvement.

\section{Methods}

In the course of the study, the main research method was the theoretical analysis of literary sources. The theoretical and methodological basis for studying the involvement of participants in educational activity is the subjective and activity-based approach (S.L. Rubinstein, A.N. Leontiev, A.V. Brushlinskii, E.A. Sergienko). This considers students and teachers as participants in the educational process. The systemic approach was applied to the components of involvement to study their unity and interrelation (P.K. Anokhin, B.F. Lomov, V.A. Barabanshchikov).

\section{Results}

After analyzing the relevant theoretical sources, we have revealed the following features of involvement: emotional and energetic [1-4]; interest and immersion in what is happening [57]; the system of external and internal forces to achieve the goals set [8]. In general, involvement is a system of interacting people that reflects the state and process of energetic involvement of its participants in joint activities with due regard to the determination of this process by external and internal factors. In the context of educational activity, this is the state and process of involvement in multi-level joint activities for the transfer, reception, assimilation and production of socio-cultural experience mediated by external and internal determinants.

Among different types, forms, aspects and components of involvement, the most common are cognitive, emotional, behavioral and motivational. On the contrary, physical, valuesbased, socio-psychological and activity-based components are less known. All of them cover the external and internal psychological space of the activity conducted by participants of the educational process.

Cognitive engagement is one of the main factors determining one's success in educational and professional activities [9-12]. It has direct and indirect characteristics. Direct ones refer to the person's cognitive abilities, including focus, memory, creative thinking [13], employees' beliefs and working conditions [14]. Indirect features include ideas about education, its need for professional development, educational institutions, benefits, accessibility and quality of education [15].

Being a construct of students' involvement in educational activities and a factor of their academic success, emotional involvement is also concerned in modern studies [9, 16-19]. In professional activities, involvement is understood as a positive or negative attitude towards a certain company and its management [14], when a person likes or dislikes their job [13], as well as has dedication to the chosen occupation [15].

Behavioral involvement is considered in the context of educational activities and is given as an outwardly expressed characteristic of activity: willingness to participate in the educational process, attend classes, follow the teacher's instructions [11-13, 17], the desire 
to undertake more efforts to establish contact [15]. It is worth mentioning that this type of involvement includes the activity of the other party, for example, the teacher's activity as search for ways to increase students' interest [15]. Accordingly, the model of involvement should be viewed as two-way activity, including the participation of both teachers and their students.

Activity-based involvement is viewed as the participation of an individual in any given activity [20] and absorption in activity [21], whose creative and transformative nature is maintained by students forming their own activity and educational role in it [22]. In this context, students not only assimilate knowledge but also produce and apply it through a dialogue with their teacher [23].

Motivational involvement can be considered in the following ways: motivation for learning $[24,25]$, activity and work; internal driving force $[8,26]$; when a person has an interest in learning and a desire to contribute to this process; willingness to make additional efforts, not limited by a job description, in achieving results that are significant for a company [29].

According to several scientific works, socio-psychological involvement $[10,28,29]$ characterizes interactions between students and teachers, students and fellow students, students and their university (environment). This feature of involvement allows us to attribute it to the methodological approach of S.L. Rubinstein [30] and his followers when any effect arising in interaction is embedded in the "person-world" system, where a person is viewed as an actor of contemplation and transformation of the surrounding world.

Physical involvement is determined by the measure of effort, physical and mental energy, the willingness to demonstrate "super-efforts" to achieve the goals set from outside or from within [27, 31], the ability to take "one step forward" from the stage of commitment [14]. The phenomenon of energy in the performance of activities was substantiated by V.M. Bekhterev more than a century ago [32].

\section{Discussion}

Within the framework of a probabilistic mental model of involvement in educational activity, we have generalized the material under consideration and its spatial-temporal aspect to determine three successive phases of such a model that includes all the listed manifestations: The first phase is preparatory or emotional-motivational embracing the emotional, motivational, values-based and semantic aspects of involvement. Thus, a setting is created to be involved and involve partners in a certain activity.

The second phase is activity-based or cognitive-behavioral, including cognitive (direct and indirect forms), behavioral, activity-based, socio-psychological and dialogical manifestations with their psychological mechanisms.

The third phase is evaluative and correctional, where the fullness (complete, partial, absent) and dominance of any aspect of involvement is determined and subsequently adjusted by teachers. An expert assessment of the preparatory and activity-based phases of involvement is conducted according to the principle: A-high level of manifestation, Bmoderate, $\mathrm{C}$-low. Teachers decide whether to make any adjustments with due regard to the received grades or self-assessment of students. Here are possible assessments for making the relevant decision: $\mathrm{AA}, \mathrm{AB}, \mathrm{BA}, \mathrm{AC}, \mathrm{CA}, \mathrm{BB}, \mathrm{BC}, \mathrm{CC}, \mathrm{CB}$.

In the context of educational activities, there are two options for implementing the involvement model: long-term and short-term. The long-term option is used by teachers in relation to the cognitive and creative perspectives of students during the preparation, joint discussion and implementation of scientific and technological projects: term paper, graduation work, thesis, joint report. There are two types of assessing the level of involvement: qualitative and expert. Both of them are determined by the student's creative 
achievement and presented in the proven Scaffolding method [30] through the components: I want-I can-I do.

The short-term option is applied in case of limited interaction between teachers and students (no more than 10 seconds), where the main result is the involvement of students in mastering the material assessed by the teacher. The "Examus" digital monitoring system records undivided attention and emotional response. This information and analytical system is based on a neural network, trained to instantly analyze the facial expressions and gestures of a person in front of the monitor, as well as to determine emotions and the degree of attention by facial expressions and behavioral patterns. The experimental results obtained by this method will be used to highlight markers of increasing involvement. Subsequently, it is necessary to increase the effectiveness of digital monitoring via the Examus system and identify psychological mechanisms of the management and self-management of students' involvement in educational activities within a digital environment.

\section{Conclusion}

The review of literary sources gives an idea about numerous aspects of involvement: cognitive, emotional, behavioral, motivational, socio-psychological and physical. We propose to divide these aspects into three phases according to the criterion of the temporal sequence of the "involvement" phenomenon: preparatory (emotional-motivational), activitybased (cognitive-behavioral) and evaluative-corrective. As a result, the spatial and temporal model of involvement in educational activity is formed which is the result of productive interaction between teachers and students on a short- or long-term basis.

\section{Acknowledgments}

The reported study was funded by the Russian Foundation for Basic Research, project number 20-0460201.

\section{References}

1. E. Klinger, Psychological Review, 82, 223-231 (1975)

2. L.I. Sokolova, E.S. Mishchenko, S.V. Ponomarev, Formirovanie podsistemy izmereniya i analiza udovletvorennosti i vovlechennosti personala v protsessy i sistemy menedzhmenta kachestva obrazovatelnoi organizatsii [Forming the subsystem of assessing and analyzing the satisfaction and involvement of staff into the quality management of educational institutions] (Izdatelstvo TGTU, Tambov, 2009)

3. M.Yu. Kondratev, Sotsialnaya Psikhologiya i Obshchestvo, 6(3), 174-188 (2015). https://doi.org/10.17759/sps.2015060314.

4. A.M. Kustubaeva, A.T. Kamzanova, Teoreticheskaya i Eksperimentalnaya Psikhologiya, 6(2) 6-13 (2013)

5. A.B. Bakker, Y. Wang, International Journal of Stress Management, 27(3), 241-251, (2020). https://doi.org/10.1037/str0000150.

6. J.W. Newstrom, Organizational behavior: human behavior at work (McGraw-Hill Education, New York, 2015) 
7. C. Truss, R. Delbridge, K. Alfes, A. Shantz, E. Soane (Eds.), Employee Engagement in Theory and Practice (Routledge, London, 2013). https://doi.org/10.4324/9780203076965

8. E.A. Aksenova, Upravlenie personalom [Staff management] (YuNITI, Moscow, 2015)

9. A. Hollingshead, P. Williamson, C. Carnahan, Field Research and Practice for Persons with Severe Disabilities, 43(4), 269-284 (2018). https://doi.org/10.1177/1540796918812803

10. K. Xie, V.W. Vongkulluksn, L. Lu, S.L. Cheng, Contemporary Educational Psychology, 62, 101877 (2020). https://doi.org/10.1016/j.cedpsych.2020.101877

11. R. Böheim, T. Urdan, M. Knogler, T. Seidel, Contemporary Educational Psychology, 62, 101894 (2020). https://doi.org/10.1016/j.cedpsych.2020.101894

12. B.D. Jones, D. Carter, Social Psychology of Education, 22(4), 819-839 (2019). https://doi.org/10.1007/s11218-019-09500-x.

13. G. Anderson, K.Y. Carmichael, T.J. Harper, T. Huang, International students at fouryear institutions: developmental needs, issues and strategies, in S.R. Harper, S.J. Quaye (Eds.), Student engagement in higher education, 17-37 (Routledge, New York, London, 2008). https://doi.org/10.4324/9780203894125

14. W.A. Kahn, E.D. Heaphy, Relational contexts of personal engagement at work, in C. Truss, K. Alfes, R. Delbridge, A. Shantz, E. Soane (Eds.), Employee Engagement in Theory and Practice, 82-96 (Routledge, London, 2013). https://doi.org/10.4324/9780203076965

15. N.V. Kiseleva, Psikhologiya i Psikhotekhnika, 4, 74-81 (2017). https://doi.org/10.7256/2454-0722.2017.4.24659

16. B. Regueiro, J.C. Núñez, A. Valle, I. Piñeiro, S. Rodríguez, P. Rosário, International Journal of Psychology, 53(6), 449-457 (2018). https://doi.org/10.1002/ijop.12399

17. J. Reeve, S.H. Cheon, H. Jang, Contemporary Educational Psychology, 62, 101899 (2020). https://doi.org/10.1016/j.cedpsych.2020.101899

18. K. Fujiwara, The Japanese Journal of Psychology, 91(2), 125-132 (2020). https://doi.org/10.4992/jjpsy.91.18232

19. N.A. Smith, J.L. Brown, T. Tran, C. Suárez-Orozco, International Journal of Psychology, 55(5), 743-753 (2020). https://doi.org/10.1002/ijop.12672

20. M. McAllister, Journal of Health Psychology, 7(5), 491-508 (2002). https://doi.org $10.1177 / 1359105302007005628$

21. K. Shaw, Strategic Communication Management, 9(3), 26-29 (2005)

22. E.R. Kahu, K. Nelson, Higher Education Research and Development, 37(1), 58-71 (2018). https://doi.org/10.1080/07294360.2017.1344197

23. A. McCulloch, V. Kumar, S. van Schalkwyk, G. Wisker, Quality in Higher Education, 22(1), 64-77 (2016). https://doi.org/10.1080/13538322.2016.1144904

24. Y.-F. Chang, B.-L. Cherng, Bulletin of Educational Psychology, 49(1), 113-136 (2017). https://doi.org/10.6251/BEP.20161028

25. W.-W. Chen, C.-C. Chen, C.-L. Dai, U.N. Man, L. Cheng, Interactive Learning Environments, 26(6), 730-744 (2018).

https://doi.org/10.1080/10494820.2017.1402061 
26. T.O. Solomanidina, V.G. Solomanidin, Motivatsiya trudovoi deyatelnosti personala [The motivation of labor activity among staff] (YuNITI, Moscow, 2009)

27. M.I. Magura, Upravlenie Personalom, 11, 20-27 (1998)

28. E.G.T. Becerra, V. Reynoso-Alcántara, Acta Colombiana de Psicologia, 22(2), 230240 (2019). https://doi.org/10.14718/acp.2019.22.2.11

29. R.L. Altman, B. Laursen, D.S. Messinger, L.K. Perry, European Journal of Developmental Psychology, 17(5), 773-785 (2020). https://doi.org/10.1080/17405629.2020.1716724

30. L.M. Popov, P.N. Ustin, Ekopsikhologicheskie issledovaniya - 6: ekologiya detstva i psikhologiya ustoichivogo razvitiya, 530-534 (FGBNU "Psikhologicheskii institut RAO”, Moscow, Universitetskaya kniga, Kursk, 2020)

31. A.W. Astin, Journal of College Student Personnel, 25(4), 297-308 (1984)

32. V.M. Bekhterev, Psikhika i zhizn [Psyche and life] (Knizhnyi Klub Knigovek, Moscow, 2012) 